\title{
SYNTHESIS FACTORS REPRESENTING CORPORATE GOVERNANCE IMPACT ON EARNINGS MANAGEMENT OF THE LISTED MANUFACTURE COMPANIES IN VIETNAM
}

\author{
LE ĐINH TRUC, NGO NHAT PHUONG DIEM \\ ngophuongdiem@gmail.com
}

\begin{abstract}
This research aims at assessing the impact of corporate governance through two synthesis factors of the Board and the Audit Committee to the behavior of earnings management through a data sample consisting of 58 listed manufacture companies from 2012 to 2016 in Vietnam securities market. The regression results according to the random estimation model measure the level of cash flow abnormality, production cost and arbitrary cost abnormality; the representative of earnings management behaviors according to Roychowdhury (2006) model acknowledges that the synthesis factor of the Board has an inverse and statistically significant correlation with the earnings management behavior. At the same time, the research also acknowledges that the control variables in regression model such as big 4 audit company and net cash flow from business activities has a negative correlation to earnings management behavior. Finally, the research has contributed to theoretical foundation on the effectiveness of the Board to limit the earnings management behavior as well as provide effective tools for listed manufacture companies as well as audit companies in decision making to preserve investment capital.
\end{abstract}

Key words. board, corporate governance, earnings management,

\section{INTRODUCTION}

Over the years, the collapse of Enron, Worldcom, Xerox ... is still an expensive lesson for the world financial market and since then, the academic community has become more and more interested in the issue of earnings management of managers. In Vietnam, the financial market in general and the securities market in particular are the channel providing nearly $50 \%$ of capital for operating enterprises. With the trend of global integration, the capital supply role of the securities market is increasingly important, gradually replacing the traditional channel of providing capital from banks. However, there are too many problems in the securities market such as financial scandals of listed companies such as: Bach Tuyet Cotton Corporation (BBT) was issued the decision to cancel listing 6.84 million of shares by Ho Chi Minh Stock Exchange on August 07, 2009; Vien Dong Pharma JSC (DVD) was released information about DVD being allowed to open bankruptcy procedures related to stock price increase, fraudulent financial reporting and fraud to the investors.

Stemming from the above problem; in the world as well as in Vietnam, there are many studies on identification models of earnings management (Healy, 1985; Jones, 1991; Dechow, Sloan and Sweeney, 1995, Roychowhury, 2006...) as well as a lot of studies examining the impact of individual characteristics of corporate governance (scale, independence, professional level, ownership rate, frequency of meetings ...) on the behavior of earnings management but the results of studies are varied widely (Chtourou et al., 2001; Klein, 2002; Xie et al., 2003, Abbott et al., 2004; Ebramhim, 2007; Swasika, 2013; Bui Van Duong and Ngo Hoang Diep, 2017, Nguyen Ha Linh, 2017 ...). Meanwhile, the manufacture industry contributes greatly to GDP, however, Nguyen Thi Phuong Hong (2016) thinks that the quality of financial statements in manufacture companies is very low. Therefore, the author conducts this research to have a unified judgment on the role of corporate governance, specifically as the role of the Board, the Audit Committee on the behavior of earnings management for manufacture industry and from that, there are suitable recommendations to improve the quality of financial statements (FS). 


\section{BACKGROUND THEORY}

\subsection{Behavior of earnings management}

According to Ronen and Yaari (2008), the earnings management is "a set of management decisions that will result in not realizing true earnings in the short term, which maximize the value of the business that the manager already knows about them. The behavior of earnings management can be beneficial (providing signals on long-term value), harm (hiding short-term or long-term value) or neutral (hiding short-term or long-term value)". This definition includes not only two types of earnings management (earnings management through selection of accounting policies and earnings management through economic activities) but also other management decisions to present earnings differently from real earnings according to manager's knowledge. However, in this study, the author only refers to the behavior of earnings management through economic activities.

\subsection{Corporate governance}

Corporate governance: according to the Ministry of Finance's definition issued under the corporate governance regulations in 2007, then corporate governance is "a system of rules to ensure that the company is oriented and controlled effectively for the interests of shareholders and people related to the company".

Carcello et al. (2006) stated that the effectiveness of corporate governance reduces the behavior of earnings management and corporate governance of a unit does not depend on the Board and the Audit Committee (Alzoubi \& Selamat, 2012). Meanwhile, in Vietnam, Circular 121/2012 / TT-BTC mentioned the corporate governance structure including the members of the General Meeting of Shareholders, the Board, the Audit Committee and the Management Committee. Therefore, this study only considers the Board and the Audit Committee representing for corporate governance to affect on the behavior of earnings management

\section{The Board}

Fama and Jensen (1983) argued that Board is an important feature of corporate governance architecture and they argue that establishing an effective Board depends on its composition. Therefore, the monitoring function of the Board is highly effective depending on the size, independent members, professional qualifications and frequency of meetings (Abbott et al., 2004; Carcello et al., 2006; Chen \& Zhou, 2007; Ronen \& Yaari, 2008). Similar to some studies of Zahra \& Pearce (1989); Alzoubi \& Selamat (2012), said that the effectiveness of the Board depends on the size, independent members, professional qualifications and frequency of meetings in the year of the Board.

Board size: Persons (2006) argued that the Board size increased the effectiveness of manager supervision of the Board, it also increased the business performance of businesses. The larger the size of the Board, the greater the diversity of experience, the diversity of expertise increases the monitoring function and can prevent or limit the behavior of earnings management more than small scale (Soliman and Ragab, 2013; Daghsni et al, 2016) as well as Xie et al (2003) argued that a large-scale Board will converge a lot of experienced and skilled members, so it will increase the quality of information and limit the behavior of earnings management.

Independent member of the Board: Independent members have the potential to detect behaviors of earnings management, all of which lead to a reduction in the level of earnings management when having their presence in the Board (Peasnell et al., 2005; Shah et al., 2009;). Some empirical studies acknowledge that companies with a higher number of independent members then the abnormal accumulation rate is low or difficult to exist behaviors of earnings management, such as Beasley (1996), Carcello et al (2002), Xie et al (2003), Peasnell (2005), Davidson et al (2005), Niu (2006), Osma (2008), .... At the same time, according to the representation theory, independent member has the ability to perform the role of supervising the operation of the Board with very high efficiency, so it is good to 
control the behavior of earnings management; therefore, in this study, the author thinks that independent member limits the behavior of earnings management.

Financial and accounting expertise ${ }^{1}$ of the Board: The Board is more effective when members of the Board have financial and accounting expertise (Carcello et al., 2002; Xie et al, 2003; Agrawal and Chadha, 2005). Because one of the roles and responsibilities of the Board is to control the process of preparing financial statements to publicize to the public. Simultaneously, Abbadi et al. (2016) demonstrated that members of the Board with financial expertise have the lowest limit to the behavior of earnings management. Therefore, the author thinks that the Board members with expertise in finance and accounting will limit the behavior of earnings management

Frequency of Board meetings: One of the responsibilities of the Board is to participate in the general meeting of shareholders, the Board meeting and receive the opinions of shareholders about business operations of the company (Ronen and Yaari, 2008). According to Ronen and Yaari (2008), if the Board meets regularly, the monitoring effectiveness of the Board will increase. Carcello et al. (2002), Ebrahim (2007), Krishnan and Visvanathan (2009), when the Board meets more and more, it shows that the company has more problems to solve, so the audit fee is higher, the quality requirement is also high, therefore, the ability to implement the earnings management is lower. Therefore, the author agrees that the more the Board meets, the more conflict will be reduced, the quality of financial statements will be increased, and the behavior of earnings management will be limited. .

The Director Duality of the Chairman of the Board: The study of Chaganti et al. (1985) suggested that, to achieve the highest monitoring efficiency, the function of the Board must be independent, who is the Chairman of the Board and CEO must be two independent individuals. At the same time, the empirical studies also acknowledge that when the Chairman of the Board concurrently holds the position of CEO / General Director, the monitoring role of the Board is not achieved, increasing the behaviors of the earnings management (Klein, 2002; Gulzar and Wang, 2011; Nugroho and Eko , 2011; Teng Philip, Lin, 2011, Soliman and Ragab, 2013; Daghsni et al., 2016). Therefore, monitoring and management functions must be separated (Weir et al, 2002). , the author also agrees that the chairman must be separated from the position of CEO.

Therefore, the author thinks that the Board effectively consists of 5 characteristics as above and the author thinks that the Board with these components increases the role of monitoring and limiting behavior of earnings management. Therefore, the research hypothesis is as follows:

H1: The effective Board has an inverse correlation with the behavior of earnings management.

Audit Committee

In joint stock companies, the Board and the Audit Committee are considered as executive agencies in the company, which runs all daily business activities. According to Carcello et al. (2006), the Audit Committee plays an important role in monitoring and ensuring financial statement quality, increasing accountability of the company. A key function of the Audit Committee is to effectively monitor the process of preparing financial statements, quality assurance, financial statement. Therefore, with its roles and functions, the Audit Committee effectively prevents the illegal behaviors. According to the study (Dezoort et al., 2002; Walker, 2004; Siregar and Utama, 2008; Alzoubi and Selamat, 2012; Metawee, 2013), it is shown that the Audit Committee with size, independence, and financial accounting expertise

' Nguyen Trong Nguyen (2015) supposed that person with financial expertise is someone who has knowledge of finance and accounting satisfying one of the following three conditions: (1) having a degree in accounting; (2) having practical experience in financial accounting or (3) any experience or training related to finance and accounting or leadership positions that are responsible for financial supervision, certified practicing auditor 
and the frequency of meetings during the year is good for the monitoring role, increasing the monitoring effectiveness of the Audit Committee.

The size of the Audit Committee: Vefeas (2005) said that the size of being too small or too large of the Audit Committee is also not good, and the most perfect members are 3 or 4 (Jensen, 1993), which increases monitoring effectiveness. Yang and Krishnan (2005), Lin et al. (2006) argued that the size of the Audit Committee has the opposite effects to the level of earnings management .

The independence of the Audit Committee: Representation theory suggests that the independence of members of the Audit Committee who are not involved in management contributes to the monitoring effectiveness of the Audit Committee (Fama \& Jensen, 1983). Abbott et al. (2004), Xie et al. (2003) argued that the independent Audit Committee shows that the company is less relevant to financial fraud and has a very low rate in relation to adjusting financial statements. Klein (2002); Ebrahim (2007); Iqbal et al. (2015) suggested that the independent member of the Audit Committee limits the behavior of earnings management and Klein (2002) in his study, indicating that a Audit Committee with 100\% independent members has no correlation with earnings management, the independence of the Audit Committee has an impact on the level of earnings management when only $50 \%$ of independent members is needed.

Experience of the Audit Committee: The Audit Committee members with financial expertise will understand the financial and accounting decisions of manager, ensure the reliability of financial statements, increase the quality of financial statements (Carcello et al, 2002; Abbott et al., 2003; Bédard et al, 2004; Xie et al., 2003) supposed that earnings management will be lesser when the members of Audit Committee had financial expertise, which is an effective method of controlling personal interests of manager and increasing corporate governance effectiveness. Defond et al. (2005), Krishnan and Visvannathan (2008), Soliman and Ragab (2014) stated that the Audit Committee with a professional level of finance will increase the effectiveness of controlling and preventing the earnings management behavior and it only needs one member of the Audit Committee to have financial expertise (Abbott et al., 2004; Bédard et al., 2004; Dhaliwal et al., 2010).

Frequency of meeting: Abbott et al. (2004) said that the Audit Committee had a large frequency of meetings, the risk of re-reporting the financial statements is lesser, not related to the penalties of frauds and the restriction of illegal legal actions (Xie et al, 2003). Ebrahim (2007) in his research has demonstrated that when the Audit Committee is active, regular meetings will improve the effectiveness of supervision, increase the quality of financial statements to limit the behavior of earnings management with the frequency of meetings at least 3 times in a year and in this study, it is also emphasizes that the monitoring effectiveness of the Audit Committee is very high if the independent members of the Audit Committee attend many meetings and are active.

Therefore, the author believes that the effective Audit Committee includes 4 characteristics as above and the author thinks that the Audit Committee with the above components will increase the role of monitoring and limiting the behavior of earnings management. Therefore, the research hypothesis is as follows:

H2 : The effective Audit Committee has an inverse correlation with the behavior of earnings management.

\section{RESEARCH METHODS}

\subsection{Data}

The sample is expected to be 223 listed manufacture companies on HOSE and HNX in the period of 2012-2016 after removing unqualified data, the total observation is 290 of 58 companies. Although data on Vietstock.vn site may be collected at any stage; however, in 2012, the Ministry of Finance issued Circular 121 / TT-BTC / 2012 regarding corporate governance regulations applicable to listed companies. 
Therefore, from 2012, information about listed companies on corporate governance is relatively adequate and listed companies also have to apply corporate governance regulations to their companies so this is the most appropriate time to collect data for research. The last point during the study period is 2016 because this is the last fiscal year published by listed companies at the time of the study.

\subsection{Research models}

This study wants to find evidence to prove that the general factors of Board of Directors and Audit Committee affect the behavior of earnings management, so the regression model includes 2 independent variables (Board, Audit Committee) and 6 control variables (company size, debt ratio, net cash flow from business operations, independent audit, Government Ownership, average stock income).

$$
R E M_{i t}=\alpha_{0}+\beta_{1 i} H \oplus Q T+\beta_{2 i} S i z e+\beta_{3 i} L e v+\beta_{4 i} C F O+\beta_{5 i} A u d i t+\beta_{6 i} O w n e r+\beta_{7 i} E P S+\varepsilon
$$

\subsection{Variable measurement}

The dependent variable is the level of Real earnings (REM), the representation of earnings management is measured according to Roychowdhury model (2006). Roychowdhury model (2006) is used because there are very few studies in Vietnam using this model to measure the behavior of earnings management of managers. Abnormal activity levels are unusual from cash flow, production costs and arbitrary discretionary costs:

Step 1 , calculate the normal amount of cash flow, production costs and discretionary costs according to the data on the financial statements.

Step 2 , study regression by the least squares method to calculate each coefficient by the following formula:

$$
\begin{aligned}
& \frac{\text { CFO }_{i t}}{A_{i t-1}}=\beta_{1}\left[\frac{1}{A_{i t-1}}\right]+\beta_{2}\left[\frac{\text { Sales }_{i t}}{A_{i t-1}}\right]+\beta_{3}\left[\frac{\Delta \text { Sales }_{i t}}{A_{i t-1}}\right]+\varepsilon_{i t} \\
& \frac{\text { PROD }_{i t}}{A_{i t-1}}=\beta_{1}\left[\frac{1}{A_{i t-1}}\right]+\beta_{2}\left[\frac{\text { Sales }_{i t}}{A_{i t-1}}\right]+\beta_{3}\left[\frac{\Delta \text { Sales }_{i t}}{A_{i t-1}}\right]+\beta_{4}\left[\frac{\Delta \text { Sales }_{i t-1}}{A_{i t-1}}\right]+\varepsilon_{i t} \\
& \frac{\text { IISEXP }_{i t}}{A_{i t-1}}=\beta_{1}\left[\frac{1}{A_{i t-1}}\right]+\beta_{2}\left[\frac{\Delta \text { Sales }_{i t-1}}{A_{i t-1}}\right]+\varepsilon_{i t}
\end{aligned}
$$

Step 3 , After having the potential coefficients into the equations to determine the degree of abnormality:

The abnormal level of cash flow

$$
R M_{-} C F O_{i t}=\frac{C F O_{i t}}{A_{i t-1}}-\left[\beta_{1} \frac{1}{A_{i t-1}}+\beta_{2} \frac{\text { Sales }_{i t}}{A_{t i-1}}+\beta_{3} \frac{\Delta \text { Sales }}{A_{i t-1}}\right]
$$

$\underline{\text { The abnormal level of production costs }}$

$$
R M_{-} P R O B_{i t}=\frac{\operatorname{PROB}_{i t}}{A_{i t-1}}-\left[\beta_{1} \frac{1}{A_{t i-1}}+\beta_{2} \frac{\text { Sales }_{i t}}{A_{t i-1}}+\beta_{3} \frac{\Delta \text { Sales }_{i t}}{A_{i t-1}}+\beta_{4} \frac{\Delta \text { Sales }_{i t-1}}{A_{i t-1}}\right]
$$

The abnormal level of useful costs 


$$
R M_{-} D I S E X P_{i t}=\frac{D I S E X P_{i t}}{A_{i t-1}}-\left[\beta_{1} \frac{1}{A_{i t-1}}+\beta_{2} \frac{\Delta \text { Sales }_{i t-1}}{A_{t i-1}}\right]
$$

Finally, REM $=R M \_C F O *(-1)+R M \_P R O D+R M \_D I S E X P *(-1)$

\section{Measurement of independent variables and control variables}

Independent variable - the Board is the combined variable of five characteristics with equal weight. According to Nguyen's study (2017), the author measures that the Board is a variable continuously receiving values from 0 to 5 and the greater the value of the Board, the more effective it is, specially:

+ The scale of the Board is a binary variable that receives the value of 1 if the number of Board members is smaller than the value of the research sample (Carcello et al. 2006).

+ The rate of independent members is a binary variable that receives a value of 1 if the independent member ratio is at least $1 / 3$ of the total number of members, otherwise 0.

+ The specialization of the Board is a binary variable that receives a value of 1 if there is at least 1 member in the Board with financial expertise, otherwise 0.

+ The frequency of meetings is a binary variable that receives a value of 1 if the frequency of meetings of the Board is greater than the average of the sample, otherwise it is 0.

+ Director Duality is binary variable that receives a value of 1 if the Chairman of the Board is separate from the position of CEO, otherwise 0 .

Independent variable - Audit Committee is a synthetic variable of four characteristics with equal weight. The author measures the variable of Audit Committee as a variable that continuously receives values from 0 to 4 and the greater the value of the Audit Committee, the more effective it is for:

The size of the Audit Committee is a binary variable that receives a value of 1 if the number of Audit Committee members is 3 and less than 5, otherwise 0 .

+ Independence of Audit Committee is a binary variable that receives a value of 1 if the minimum membership ratio is at least $50 \%$ of the total members, otherwise 0 .

+ The specialization of the Audit Committee is a binary variable that receives a value of 1 if there is at least 1 member in the Audit Committee, otherwise 0.

+ The frequency of meetings of the Audit Committee is a binary variable that receives a value of 1 if the frequency of meetings of the Audit Committee is greater than the average of the research sample, otherwise 0

\section{Control variable}

Company size (Size), according to research by Sirat (2012), Akbari (2013); Soliman and Ragab (2013) shows that the size of the company has a negative impact on the behavior of earnings management and this study also agrees with this view. The Size variable measures according to the base $10 \log$ of the total asset.

Cash flow operations (CFO), Research of Moradi et al (2012), Peasnell et al (2005), Bowen et al. (2008) argued that cash flow of business activities limited the behavior of earnings management and in this study, CFO can limit earnings management behavior, measured by CFO/ total assets.

Government Ownership (OWNER): Chen et al. (2010) argued that enterprises owning state capital, the manager has a remuneration regime with many political and social objectives in addition to 
ensuring operational results (Fan et al, 2007). so earnings management is less practiced. Therefore, the author thinks that Government Ownership reduces the behavior of illegal employment.

Debt ratio (LEV): Some studies have suggested that the use of debt ratios promotes businesses to work more effectively, limit the risk of earnings management behavior (Naz et al., 2011; Zamri et al, 2013). Therefore, the author supports the view that the higher the debt, the lower the level of earnings management and in the author study, the debt ratio is the coefficient between the total liabilities on the total assets.

Average income per share (EPS): Jordan et al. (2010) Ohlson (1995) argue that EPS increases the level of earnings management. Therefore, the author thinks that companies with larger average income will increase the behavior of earnings management

Auditing company (AUDIT), research by Xie et al. (2003), Chen et al. (2005) admitted that companies that are audited by Big4 limit the behavior of earnings management. Therefore in this study, the AUDIT variable is a binary variable that receives a value of 1 if it is audited by Big 4 or vice versa.

\section{RESEARCH RESULTS}

In order to assess the impact of the factors of the Board on the management of earnings management, research using stata 12 software is a tool to support analysis.

First, to make a preliminary assessment of the data of the regression model, the study implemented descriptive statistics. According to the results of Table 1 and Table 2, there is an existence of the lowest quality management with the lowest reduction of asset management by $-214 \%$ compared to the beginning of the year and the highest growth rate of $80 \%$ at the beginning of the year. Other statistical results are also detailed in tables 1 and 2 .

Table 1. Descriptive statistics of quantitative variables

\begin{tabular}{|c|c|c|c|c|c|}
\hline Variable & observed & average & $\begin{array}{c}\text { Standard } \\
\text { deviation }\end{array}$ & Min & Max \\
\hline REM & 290 & 0.147992 & 0.2494466 & -2.145864 & 0.806512 \\
\hline BD & 290 & 2.437931 & 0.8784166 & 1 & 5 \\
\hline AC & 290 & 3.341379 & 0.6313698 & 2 & 4 \\
\hline SIZE & 290 & 11.90081 & 0.6159699 & 10.2653 & 13.52149 \\
\hline LEV & 290 & 0.465089 & 0.2140799 & 0.04723 & 0.966925 \\
\hline CFO & 290 & 0.092771 & 0.1364729 & -0.3903 & 1.189263 \\
\hline EPS & 290 & 2708.591 & 2807.05 & -10332 & 13796 \\
\hline
\end{tabular}


Table 2. Descriptive statistics of qualitative variables

\begin{tabular}{|ll|c|c|c|}
\hline \multicolumn{1}{|l|}{ Variable } & frequency & ratio (\%) & Total (\%) \\
\hline \multicolumn{1}{|l|}{ Audit } & & & \\
\hline & 0 & 212 & 73.1 & 73.1 \\
\hline 1 & 78 & 26.9 & 100 \\
\hline Owner & & & 73.45 \\
\hline & 0 & 213 & 73.45 & 100 \\
\hline & 77 & 26.55 & \multicolumn{2}{|c|}{ Source: The author deals with stata 12 software }
\end{tabular}

In order for the regression model to have enough predictive values, the study conducted to examine the correlation between variables and multicollinearity, the results shown in Table 3 show that the variables in the regression model have no correlation intimate (correlation coefficient $<0.8$ ) and not having multicollinearity phenomenon $($ Vif $<10)$.

Table 3. Testing the correlation between variables and multicollinearity phenomenon

\begin{tabular}{|c|c|c|c|c|c|c|c|c|c|c|}
\hline VARIABLE & REM & $\mathrm{BD}$ & $\mathrm{AC}$ & SIZE & LEV & $\mathrm{CFO}$ & EPS & AUDIT & OWNER & VIF \\
\hline REM & 1 & & & & & & & & & \\
\hline BD & $-0,026$ & 1 & & & & & & & & 1.03 \\
\hline $\mathbf{A C}$ & $-0,147$ & 0.0023 & 1 & & & & & & & 1.28 \\
\hline SIZE & $-0,053$ & 0.0186 & 0,161 & 1 & & & & & & 1.79 \\
\hline LEV & 0,173 & 0.0118 & $-0,372$ & 0,198 & 1 & & & & & 1.48 \\
\hline CFO & $-0,296$ & 0.0287 & 0,164 & 0,016 & -0.21 & 1 & & & & 1.06 \\
\hline EPS & 0,019 & 0.0258 & 0,193 & 0,234 & $-0,284$ & 0,134 & 1 & & & 1.22 \\
\hline AUDIT & $-0,203$ & $-0,119$ & 0,301 & 0,563 & -0.14 & 0,077 & 0,270 & 1 & & 1.71 \\
\hline OWNER & $-0,137$ & $-0,063$ & $-0,028$ & -0.11 & 0,026 & 0,019 & -0.04 & $-0,047$ & 1 & 1.02 \\
\hline mean vif & & & & & & & & & & 1.32 \\
\hline
\end{tabular}

Source: The author deals with stata 12 software

In addition, to base on the regression model to argue, the study conducted to test the variance change and the phenomenon of autocorrelation. Research using two White tests and Woolridge testing with Prob $>$ chi $2=0.8039$ results and Prob $>F=0.9353$ are greater than the $5 \%$ significance level, meaning the model has constant and non-existent variance at the phenomenon of autocorrelation.

Finally, after implementing F tests, LM tests, Hausman tests, the random estimation model is the best estimation model with the results shown in Table 4.

Table 4. Regression by random estimation method

\begin{tabular}{|l|r|r|r|r|r|r|}
\hline REM & Coef. & Std. Err. & Z & P $>$ Z & [95\% Conf. & Interval] \\
\hline BD & -0.029499 & 0.017886 & -1.65 & $0.099 *$ & -0.064555 & 0.00556 \\
\hline AC & -0.020448 & 0.02923 & -0.7 & 0,484 & -0.077736 & 0.03684 \\
\hline SIZE & 0.0563991 & 0.039461 & 1.43 & 0,153 & -0.020942 & 0.13374 \\
\hline LEV & 0.0252138 & 0.095743 & 0.26 & 0,792 & -0.162439 & 0.21287 \\
\hline CFO & -0.477357 & 0.093169 & -5.12 & $0.000 * * *$ & -0.659966 & -0.2947 \\
\hline EPS & $6.17 \mathrm{E}-06$ & $5.91 \mathrm{E}-06$ & 1.05 & 0,296 & $-5.40 \mathrm{E}-06$ & $1.8 \mathrm{E}-05$ \\
\hline
\end{tabular}




\begin{tabular}{|l|r|r|r|r|r|r|}
\hline AUDIT & -0.182387 & 0.047587 & -3.83 & $0.000 * * *$ & -0.275655 & -0.0891 \\
\hline OWNER & -0.036117 & 0.036288 & -1 & 0.32 & -0.10724 & 0.03501 \\
\hline cons & -0.287831 & 0.454655 & -0.63 & 0,527 & -1.178938 & 0.60328 \\
\hline
\end{tabular}

With: *; *** at 10\% significance level; and 1\%; Dependent variable is REM according to Roychowdhury model (2006)

$$
R^{2} \text { coefficient adjusted: } 14.35 \% ; n=290 \text { observed; Wald chi2 (8) }=49.51 ; \text { Prob }>F=0.000
$$

Source: The author deals with stata 12 software

With the regression results in Table 4 shows: Independent variables (Board, Audit Committee) and 6 control variables explain $14.35 \%$ variation of REM variable, meaning that the change of the earnings management level is explained by $14.35 \%$ of changes of independent variables and variables control. Simultaneously with the coefficient Prob $>$ F $=0.000$ means the model is reliable enough to estimate and argue the results.

Variable Board (BD) has a negative correlation with REM and is significant with $90 \%$ confidence. It means that the Board effectively increases the role of monitoring and limiting the behavior of earnings management to increase the quality of financial statements. This result supports the representative theory that the effectiveness of the Board reduces the conflict between owners and managers, in accordance with the judgment of Carcello et al. (2006), supporting the viewpoint of theory to Granovetter (1978) considers that a small change in the elements of the whole will make the whole population change greatly. At the same time, this result supports resource-dependent theory that the Board meets the requirements of resources (independent members, number of members, financial and accounting expertise, part-time and number of times). meeting) to increase the effectiveness of monitoring and limiting the behavior of account management, similar to the assessment that the Board has a diverse structure and functions to increase the quality of financial statements (Hoang, 2014) or in accordance with research results Research by Carcello et al. (2006) when it is shown that strong corporate governance reduce earnings management behaviors, increase the quality of information on financial statements.

Control variable CFO: With coef coefficients $=-0.477357$, P-value $=0.000$ means that CF0 variable limits the behavior of earnings management at $1 \%$ significance level. Research results support signal theory and are explained when enterprises with large cash flows from business activities will be very cautious in implementing policies that may affect the reputation and value of the company in the future. so the company tends to limit the behavior of earnings management and is consistent with the judgment of Peasnell et al (2005); Bowen et al. (2008); Moradi et al. (2012).

Control variable AUDIT: With coef coefficient $=-0.182387$, P-value $=0.000$ means that the AUDIT variable has the opposite effect to the earnings management and is statistically significant at the $1 \%$ significance level . Research results are similar to those of Xie et al. (2003), Chen et al. (2005).

At the same time, the research results found no evidence that the overall control factor and remaining control variables (SIZE, LEV, EPS, OWNER) correlated with the behavioral management through economic activities.

\section{CONCLUSION AND CONTRIBUTION OF RESEARCH}

Through regression results, the study has provided credible evidence when admitting the Board effectively with five characteristics of independence, scale, financial and professional qualifications, frequency of meetings and non- The task of limiting the behaviors of business promotion through economic activities. At the same time, the research results also provide evidence that the AUDIT and CFO variables limit the behavior of job hunting. In addition, the study did not find evidence of the impact of the Audit Committee, SIZE, LEV, EPS, OWNER to earnings management. 
Based on research results that provide evidence that representation theory, behavioral theory, signal theory is the basis for the need to establish a typical manager monitoring mechanism, the Board to reduce minimizing conflicts of interest, reducing asymmetric information between manager and shareholders. At the same time, it also provides evidence that resource-dependent theory is the basis for explaining that the components of the Board must have the necessary characteristics such as the number of members, independent members, qualifications, the frequency of meetings, the non-concurrent position, the Board is effective, well performing the role of supervising the executive activities of the manager, reducing conflicts of interest, limiting the risk of illegal business operations. Therefore, this study has contributed to the treasure of scientific knowledge about the synthesis factor of the Board affecting the behavior of QoS, as a solid foundation for other future studies on corporate governance research and Human Resource Management At the same time, the research provides a basis for CTSPs to see the role of corporate governance effectively in increasing the quality of financial statements, limiting the behavior of earnings management, in order to build the structure of the Board in accordance with the regulations of corporate governance. follow Decree 71/2017 / ND-CP on the spirit of voluntariness, thereby perfecting the corporate governance system to become an effective corporate governance. In addition, the study also contributes useful tools for auditing companies, auditors and investors to preliminarily evaluate the behavior of earnings management through the evaluation of the general factors of the Board, thereby serving the effective auditing planning, limiting audit risks as well as making appropriate decisions.

\section{REFERENCES}

[1] Abbott, J.L, Parker.s, Peters, F.G., (2004). Audit committee, Characteristics and restatement. A journal of Practice \& Theory, Vol. 23, No. 1, p. $69-87$.

[2] Agrawal, A., \& Chadha, S., (2005). Corporate governance and accounting scandals. Journal of Law and Economics, 48(2), p. $371-406$.

[3] Alzoubi, E.S.S., Selamat, M. H. (2012). The effectiveness of Corporate Governance mechanisms on constraining earnings management: Literature review and procced framework. International Journal of Global Business, 5(1), 17 -35.

[4] Alzoubi, E. S. S., (2016). Audit quality and earnings management. Journal of Applied accounting Research, Vol 7, Iss 2.

[5] Akbari, M.A (2013). Impact of firm size and capital structure on Earnings management:Evidence from Iran. World of Sciences Journal. Vol. 1, No 17, p. 59 -71.

[6] Beasley, Mark S.(1996). An empirical analysis of the relation between the board of director composition and financial statement fraud. The Accounting Review, Vol. 71, p.443 -465.

[7] Bowen, R. M.; Rajgopal, S. and Venkatuchalam, M., (2008). Accounting Discretion, Corporate Governance and Firm Performance. Contemporary Accounting Research, Vol 25, No 2, p. 351 - 405.

[8] Bui Van Duong and Ngo Hoang Diep, (2017). Characteristics of the Board and Behavior of earnings management of listed companies on Vietnam securities market. Scientific Journal of Ho Chi Minh Open University, 54 (3), 2017

[9] Carcello, J.V., Hermanson, D.R., Neal, T.L., and Riley, R.A., (2002). Board characteristics and Audit free. Contemporary Accounting Research, 19(3), 365 -384

[10] Carcello, J.V., Klein, A., and Neal, T.L., (2006). Audit committee Financial expertise competing Corporate governance Mechanisms, and earnings management. Available at SSRN: https://ssrn.com/abstract=887512 or http://dx.doi.org/10.2139/ssrn. 887512 
[11]Chaganti, R.S., Mahajan, V. and Sharma, S., (1985). Corporate board size, composition and corporate failures in relating industry. Journal of management Studies, 22(4): $400-417$.

[12] Chen, K.Y., \& Zhou,J. (2007). Audit Committee, Board Characteristics and auditor Swich Dicisions by Andersen's Clients. Contemporary Accounting research, 24(4), 1085- 1117.

[13] Chen, K. Y.; Lin, K. L. and Zhou, J. (2005). Audit quality and earnings management for Taiwan IPO Firms. Managerial Auditing Journal, Vol 20, No 1, P 86 - 104.

[14] Chtourou, S.M; Bédard, J. and Courteau, L. (2001). Corporate Governance and Earnings Management. http:/SSRN.com/abstract $=275053$

[15] Daghsni, 0., Zouhayer, M., and Mbarek, K.B.H., (2016). Earnings management and Board characteristics: evidence from French listed Firms. Accounting and Financial management Journal, Vol. 1, Issue 2, 92 100. (Doi: 10.1234.67/afmj 1009)

[16]Davidson, R., Goodwin - Stewart, J., \& Kent, P. (2005). Internal governance structures and earnings management. Accounting \& Finance, 45(2), p. $241-267$

[17] Dechow, P. M., Sloan, R. and Sweeney, A.P., (1995). Detecting earnings management. The Accounting Review. Vol.70, p.193-225.

[18] DeZoort, F. T, Hermanson, D.R., Archambeault,D.S \&Reed,A.S (2002). Audit committee effectiveness: a synthesis of the empirical audit committee literature. Jounal of Accounting Literature, 21, 38-75.

[19]Dhaliwal, D., Naiker, V. and Navissi, F. (2010). The association between accruals quality and the characteristics of Accounting experts and Mix of Expertise on Audit committees. Contemporary Accounting Research, Vol.27, no.3, p. 787 - 827.

[20] Ebrahim (2007). Earnings management and board activity: an additional evidence. w.w.w emerald in sight.com/1475-7702.html

[21] Fama. E.F and M.C Jensen (1983). The separation of Ownership and control, The Journal of Law and Economics, 26 (June), p.301-325.

[22] Hoang, C.T, (2014). Board Diversity, Earnings quality and corporate social Disclosure: evidence from Vietnamese Listed firm. University of Wollongong Thesis Collection, 1954 -2016.

[23] Iqbal,A.; Zhang, X., and Jebran, K. (2015). Corporate governance and earnings management: A case of Karachi Stock exchangs listed companies. Indian Journal of corporate governance, vol. 8.p. 103-118.

[24] Jelinek, K. (2007). The Effect of Leverage Increases on Earnings Management. Journal of Business \& Economic Studies, 13(2), p.24-46.

[25]Jensen, M.C (1986). Agency Costs of Free Cash Flow, Corporate Finance and Takeovers. American Economics Review, 76(2), p.323-329.

[26] Jones, J. J. (1991). Earnings management during import relief investigation. Journal of Accounting Research, Vol.29, p.193-228.

[27] Jordan, C.E.; Clark, S.J., and Hames, C.C., (2010) The impact of audit quality on earnings management to achieve user reference points in EPS. The journal of applied Business Research, Vol. 26, pp. 19-30.

[28] Kao, L., and Chen, A. (2004).The Effects of Board Characteristics on Earnings Management. Corporate Ownership \& Control. Australasian Accounting, Business and Finance Journal, Vol. 1. No.3. Pp: 96-107. 
[29] Klein, A. (2002). Audit Committee, Board of Director Characteristics, and Earnings Management. Law \& Economics reserch paper series working paper, No 06-42.

[30] Krishnan, G.V, \& Visvanathan, G., (2008). Does the SOX Definition of an Accounting Expert Matter? The association between Audit committee Directors' Accounting Expertise and Accounting Conservatism. Contemporary Accounting Research, 25(3), p. 827- 858.

[31]Lin, J., Li, J., and Yang, J., (2006). The Effect of Audit Committee Performance on Earnings Quality. Managerial Auditing Journal, Vol. 21, No. 9. p. 921-933.

[32] Naz,I; Bhatti, K.; Ghafoor, A., Khao, H.H, (2011). Impact of firm size and capital structure on Earnings Management, evidence from Pakistan. International Journal of contemporary Business studies, Vol. 2, N 12 , p $22-31$

[33] Nguyen, T.M.N, (2017). Earnings management: detection, application and contagion. Doctor of philosophy Thesis, University of Kent.

[34] Nguyen Thi Phuong Hong, (2016). Factors affecting the quality of financial statements of listed companies on the securities market - Experimental evidence in Vietnam. Economic doctoral thesis, Ho Chi Minh City University of Economics.

[35]Nguyen Trong Nguyen (2015). The impact of corporate governance on the quality of financial statements at listed companies in Vietnam. Economic doctoral thesis.

[36] Nugroho. B.Y and Eko.U (2011) Board characteritics and Earnings Management. Journal of Administrative Science \& Organization, January 2011, pp 1-10.

[37] Metawee, A., (2013). The relationship between characteristics of audit committee, board of directors and level of earning management, Evidence from Egypt. Journal of International Business and Finance, Plymouth Business School, UK

[38] Moradi, M. et al (2012), A Study of Relationship between Board Characteristics and Earning Management: Iranian Scenario, Universal Journal of Management and Social Sciences, Vol.2, No.3.

[39] Ohlson, J. (1995). Earning, Book values and Dividends in Equity Valuation. Contemporary Accounting Reasearch, Vol. 11, No.2, p $661-687$.

[40] Osma, B.G. (2008). Board Independence and real Earnings Management: The case of R \&D Expenditure. Corporate governance: An international Review, vol.3, p. 231 - 260.

[41] Peasnell, K.V, Pope, P.F, and Young, S. (2005). Board monitoring and Earnings Management: Do outside Directors Influence Abnormal Accruals? Journal of Business Finance and Accounting, Vol.32, p.1131 1346.

[42] Persons, O.S., (2006). Corporate governance and Non - Financial Reporting Fraud. The journal of Business and economic studies, Spring 2006, 12;1 Proquest central, P. 27

[43] Ronen, J \&Yaari (2008). Earnings management: Emerging insights in theory. Practice and research. (vol.3) NewYork: springer.

[44] Roychowdhury, S. (2006). Earning Management through Real Activities Manipulation. Journal of Accounting and Economics, 42(3), p.335-370. 
[45] Xie, B., Davidson, W. and Dadalt, P. (2003). Earnings Management and Corporate governance: The role of the Board and the Audit Committee. Journal of Corporate Finance, vol.9, p. 295 - 316.

[46] Shah, S., Nousheen, Z., and Tahir, D. (2009). Board ComDA dươngition and Earnings Management an Empirical Evidence from Pakistani listed companies. Middle Eastern Finance and Economics, Vol. 3, p. 28 -38 .

[47] Shleifer, A. and Vishny, R.W. (1997). A survey of corporate governance. The Journal offinance, 52 (2), p. $737-783$.

[48] Sirat, H.,(2012). Corporate governance practices, Share ownership Structure and size on earnings management. Jounal of economics, Business and Accountancy Ventura Accreditation, Vol 15, No.1, pp. $145-156$.

[49] Soliman, M. M, and Ragab, A. A. (2013). Board of Director's Attributes and Earning Management: Evidencefrom Egypt. International Business and Social Sciences Research, Conference 3 - 4 January, 2013.

[50]Soliman, M. M, and Ragab, A. A. (2014). Audit committee effectiveness, audit quality and Earning Management An Empirical Study of the Listed Companies in Egypt. Research Journal of Finance and Accounting, Vol 5, No 2

[51] Swastika, D. L. T., (2013). Corporate Governance, Firm Size, and Earning Management: Evidence in Indonesia Stock Exchange. Journal of Business and Management, Vol. 10, P. 77-82

[52]Teng Philip, Lin (2011). Corporate governance mechanisms and earnings management in transitional countries - evidence from Chinese listed firms. PhD Thesis, Queensland University of Technology.

[53] Wang, L., and Yung, K., (2011). Do State Enterprises Manage Earnings More than Privately Owned Firms? The Case of China. Journal of Business Finance \& Accounting, 38 (7-8): 794-812

[54] Walker, R. (2004). Gaps in guidelines on audit committees. Abacus, 40(2), p. 157 - 192.

[55] Waweru, N.M; Riro, G. K (2013). Corporate governance, Firm characteristics and Earnings Management in an Emerging economy. Jamar, Vol. 11, p. 43 - 64.

[56] Weir, C. Laing, D., and McKnight, P.J. (2002). Internal and external governance Mechanisms: Their impact on the performance of large UK public companies. Journal of Business Finance \& Accounting, Vol. 29, No. 5, p. $579-611$.

[57]Zamri, N, Rahman R. A, and Iya. N.S.M (2013). The impact of leverage on real earnings management. Procedia Economics and Finance, Vol.7, 86-95.

Received on February 1st, 2019

Accepted on March 25th, 2019 